\title{
EVALUATION OF INVESTMENT AND RETURN IN INFORMAL SECTOR: A CASE OF CHITWAN DISTRICT
}

\author{
Ramchandra Dhakal*
}

\begin{abstract}
Developing counties, like Nepal is still in tense to maintain the level of political stability, economic growth, development, and employment which are the main issues in one side of the economy and on the other, the majority of the people find shelter in the informal sector in the absence of sluggish growing formal sector. Most of the people are engaged in informal economies that have created varying effects on them in terms of employment and income generations. The latter seems to be determined mainly by the household property, level of literacy, the number of persons employed in any unit and investment. However, there is no apparent differentiation in the income earnings between males and females, the latter seems to be more efficient and articulate in many ways. Income earnings have been higher in the urban location than that of the rural sector. Income level and the determining factors seem to vary among different location and sexes. This study tries to compare the nature and characteristics of informal sector both at national as well as international levels. The government must play effective policy as well as to uplift informal economy for the economic development as a whole. To identify the informal sector properly in Nepal, a national wide survey that covers overall aspects should be considered before taking any step.
\end{abstract}

Key words: Informal Economy, Informal Sector, Investment, Literacy Level, Occupation, Poverty, Tax Evasion, Unemployment.

\section{INTRODUCTION}

Nepal being a developing economy bears some common characteristics such as low level of development and highly instable pattern of economic growth passes through many phases of political instability with heterogeneous nature. It is also experienced with the democratic system, however the recent experiment does not seem to be quite encouraging for sustainable growth. Its economic implications might be in the form of weak strategy with regard to economic growth and development. The country has not been able to show satisfactory economic growth rate that might be considered sufficient high and sustainable to tackle the chronic poverty, unemployment and lack of economic opportunities. Under these circumstances, undoughtly the informal sector has been occupying significant space of the country.

By sharing the experiences of other countries, all over the world, the share of informal employment, that is jobs performed outside the formal structures that govern taxes, workplace regulations and social protection schemes seemed to be very high, and increasing. Informal economy could be defined as all activities carried out outside the

Dr. Dhakal is an Associate Professor at Central Department of Economics, T.U., Kirtipur, Kathmandu, Nepal. 
formal sector including self-employed workers and wage-workers informal economy. Thus, it refers to "all economic activities that are...in law or in practice...not covered or insufficiently covered by formal arrangements" (Hussmanns, 2004).

An average if, over half of all jobs in the non-agricultural sectors in developing and emerging economies are in existence, it can be considered informal. In some regions, including sub-Saharan Africa and South Asia, this rate is even higher upto 80 percent of all non-agricultural jobs and, for a few countries, higher (Huitfeldt, Jütting, and Jütting, 2009). If informal employment in agriculture is included, the share of informal employment in total employment becomes even higher: as high as 90 percent in many countries of South Asia and sub-Saharan Africa (Chen Vanek, Lund, Heintz, Jhabvala, and Bonner, 2005).

Informality is not necessarily synonymous with poverty and the "working poor" (who earn less than enough to generate a family income of US\$1 per day per capita) and can be found in both formal and informal jobs, indeed higher percentage of people working in the informal relative to the formal economy are poor, and more than that a larger share of women compared to men working in the informal economy are poor. Workers working in informal sector encounter many difficulties that must be addressed by both the state and the non-state actors. Moreover a lack of recognition and protection under the legal and regulatory framework of the state, informal workers and entrepreneurs are characterized by a high degree of vulnerability (International Labor Organization (ILO), 2002).

Nepal stood to be ranked first in Asia being among the poorest states along with most unequal societies. In this connection, 50.4 percent of poor people working do not earn enough to lift themselves and their families above the US\$ 1.25 a day poverty line, and the US\$ 2 a day poverty line is being undercut by 74.1 percent of workers (ILO, 2010). Nepalese inequality could be expressed in different ways with various categories such as economic inequality, religious inequality (mostly caste), traditional regional inequality and gender inequality. Consequently, the inclusiveness of economic growth (the most effective way to reduce poverty in a country) and employment creation measures are on the very forefront in order to secure long-term stability.

\section{THEORETICAL AND CONCEPTUAL FRAMEWORKOF INFORMAL ECONOMY}

The economic terminology of the formal and informal sector was first introduced by J. K. Hart in his paper with the reference of urban employment in Ghana. He used the concept to describe a part of urban labor force, who works outside formal labor market. However, dualist thinking was in the existence before his terminology in general existed. Hart divided the economy into formal (analogous to the previously used term 'modern') and informal (previously 'traditional') sectors and he put emphasis on the significance of self-employment and small enterprises and the degree of statistical under-recording in the informal sector.

Nowadays, the terms informal sector and informal economy are widely used in writings by both, developed and developing countries. They are referred to the street vendors in Bogota, shoeshine workers in Calcutta, specialized knitwear makers in Modena and producers of fashion garments in New York respectively. However those activities appear to have in common is a mode of 
organization different from the unit of production is most familiar in economic theory, the firm or corporation. These activities are mostly unregulated by the state thus to be excluded from standard economic accounts of national income.

The informal economy encompasses a multitude of dispersed operational units and activities. Obviously it differs from the formal economy in terms of technology, economies of scale, the use of labor intensive processes for producing goods and services, and a virtual absence of well-maintained accounts. The government does not regulate informal economy, and lacks state controls. Hence, the probability of exploitation is much higher (ILO, 2004).

Table 1: Key Differences between the Formal and Informal Economy

\begin{tabular}{|l|l|}
\hline \multicolumn{1}{|c|}{ Formal } & \multicolumn{1}{c|}{ Informal } \\
\hline Formal contact and letter of appointment & Verbal contact and no appointment \\
\hline Regularity of Employment & Irregularity of employment \\
\hline Fixed wage rate & Uncertain wage rates \\
\hline Fixed working hours & Uncertain working hours \\
\hline Legal provisions of protection & No legal provisions of protection \\
\hline
\end{tabular}

Source: ILO, social protection for people in the informal economy of Nepal, Table-2, p. 6, KTM, Nepal, 2004.

\section{CONCEPTUAL TERMINOLOGY}

The terminology regarding the informality of employment is however not uniform and the concepts might be confusing. Informal sector and Informal economy are the most commonly used terms, but one will also find a variety of other terms referring to informality such as non-standard, atypical, alternative, irregular, precarious, and unorganized and so on. Informal sector and Informal economy are often used synonymously; even so one significant difference is existed. Informal economy is a wider term, which includes the narrower term informal sector. Informal economy is defined as "all economic activities by workers and economic units that are- in law or in practice- not covered or insufficiently covered by formal arrangements" (ILO, 2002). The ILO report on 'Decent work and the Informal Economy' defined employment in the informal economy as comprising two components: (i) employment in the informal sector as defined by the $15^{\text {th }}$ International Conference of Labor Statistician (ICLS), and (ii) other forms of informal employment (i.e. informal employment outside the informal sector).

This leaves two different concepts which need clarification, since both are used to measure the informal economy and because the Nepal Labor Force Survey (NLFS), which provides the statistical data for this study, uses both concepts: employment in the informal sector as well as informal employment.

\section{STATISTICAL DEFINITION OF 'EMPLOYMENT IN THE INFORMAL SECTOR}

The $15^{\text {th }}$ ICLS defined employment in the informal sector as comprising all jobs in informal sector enterprises, irrespective of their status in employment and whether it was their main or a secondary job (Hussmanns, 2004). Since, This is a definition based on enterprise. According to the $15^{\text {th }}$ ICLS, informal sector enterprises are private unincorporated enterprises owned by individuals or 
households that are not constituted as separate legal entities independently of their owners, and for which no complete accounts are available that would permit a financial separation of the production activities of the enterprise from the other activities of its owner(s). This is a form of unincorporated enterprises owned and operated by individual household members or by several members of the same household, as well as unincorporated partnerships and co- operatives formed by members of different households, if they lack complete sets of accounts. This excludes the production of those goods which are solely produced for their own consumption, units in the agricultural sector and units above a certain threshold to be determined according to national circumstances (Hussmanns, 2005).

The NLFS of 2010 uses accordingly three questions to determine whether a person whose main job is not in agriculture will be accounted as being employed in the informal sector: (1) Employment (economic) status (2) Institutional sector of employment (3) Number of employees. If a person fulfills all above mentioned criteria in a single row, he/she will be accounted as working in the informal sector (Table 2).

The threshold level remains dependent according to the law of the individual country. In India, for example, companies with more than 20 employees are considered to be in the formal sector and this number is even lower if the respective company is connected to the local grid. Nepal Labor Force Survey $(1998 / 99,2008)$ has used 9 as the maximum number of employees for units to be categorized as belonging to the informal sector. Due to the difficulty of defining informal economy activities in the agricultural sector the NLFS, as most other labor surveys on the informal economy following ILO recommendations only considers the informal economy with respect to the non-agricultural sector.

Table 2: Classifications of non-agricultural jobs into the informal sector according to ILO and NLFS (NLFSs 1998/99 and 2008)

\begin{tabular}{|l|c|c|}
\hline \multicolumn{1}{|c|}{ Employment status } & Institutional sector & $\begin{array}{c}\text { Number of } \\
\text { employees }\end{array}$ \\
\hline Paid employees & $\begin{array}{l}\text { Private unregistered } \\
\text { company or other }\end{array}$ & Less than 10 \\
\hline $\begin{array}{l}\text { Operating own business with } \\
\text { no employees }\end{array}$ & - & - \\
\hline $\begin{array}{l}\text { Operating own business with } \\
\text { Regular paid employees } \\
\text { Or unpaid family members or other }\end{array}$ & - & Less than 10 \\
\hline
\end{tabular}

Note: Other ref Sources: Nepal Labour Force Survey, Central Bureau of Statistics, National Planning Commission Secretariat, Government of Nepal, 2008.

The concept of employment in informal sector only refers to informal establishments or micro enterprises. The informal sector looks at employment in terms of characteristics of the production units (enterprises) in which the activities take place (enterprise approach), rather than in terms of the characteristics of the persons involved or of their jobs (labor approach). It does not mention informal activities or informal employment beyond of its concept and thus the statistical framework. As this leaves gaps in the statistical coverage 
of the informal economy, it has been heavily criticized. Thus the need of a broader definition is essential which encompasses the whole informal economy (Hussmanns, 2004). For this reason the 17th International Conference of Labor Statisticians added the concept of Informal Employment in 2003 within the existing set of international standards. Hence the differences become more obvious when viewed from the perspective of statistical information gathering.

\section{STATISTICAL DEFINITION OF INFORMAL EMPLOYMENT}

By observing the conceptual framework of informal employment as endorsed by the 17th ICLS relates the enterprise-based concept of employment in the informal sector to a broader, job-based concept of informal employment. Since a person can have two or more formal and/or informal jobs (multiple jobholders). Here the jobs rather than employed persons were taken as the observation units for employment. The jobs can be described by various job related characteristics and the jobs are undertaken in production units (enterprises) that can be described by various enterprise-related characteristics. This framework uses two dimensions: type of production unit and type of job.

The production units can be classified into three major groups: (1) Formal Sector Enterprises, (2) Informal Sector Enterprises and (3) Households. Jobs are distinguished according to status-in-employment categories and according to their formal or informal nature. Again following five groups are used to identify the status in employment, each one is then again split into formal and informal: (1) Own-account Workers, (2) Employers, (3) Contributing Family Workers, (4) Employees and (5) Members of Producers' Cooperatives.

The statistical differences adapted by ILO between Informal Employment, Employment in the informal sector and Informal employment outside the informal sector which has depicted in following Box 1.

Box 1: Classification of Jobs Recommended by the ILO

\begin{tabular}{|c|c|c|c|c|c|c|c|c|c|}
\hline \multirow{3}{*}{$\begin{array}{l}\text { Production } \\
\text { unit by type }\end{array}$} & \multicolumn{9}{|c|}{ Jobs by Status of Employment } \\
\hline & \multicolumn{2}{|c|}{$\begin{array}{c}\text { Own account } \\
\text { workers }\end{array}$} & \multicolumn{2}{|c|}{ Employers } & \multirow{2}{*}{ 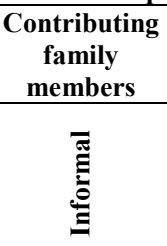 } & \multicolumn{2}{|c|}{ Employees } & \multicolumn{2}{|c|}{$\begin{array}{c}\text { Members of } \\
\text { producer } \\
\text { cooperatives }\end{array}$} \\
\hline & 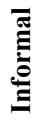 & & 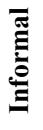 & 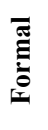 & & $\begin{array}{l}\overline{\mathfrak{E}} \\
\stackrel{\Xi}{\Xi} \\
\stackrel{\Xi}{\Xi}\end{array}$ & 焉 & 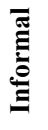 & 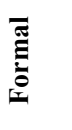 \\
\hline $\begin{array}{l}\text { Formal sector } \\
\text { enterprises }\end{array}$ & & & & & & & & & \\
\hline $\begin{array}{l}\text { Informal sector } \\
\text { enterprises }\end{array}$ & & & & & & & & & \\
\hline House-holds & & & & & & & & & \\
\hline
\end{tabular}

Source: Note is at the end of conclusion section.

The NLFS has not separately identified members of producer cooperatives and does thus not provide data for the specific field. 


\section{EVALUATION OF INVESTMENT AND RETURN ...}

\section{INFORMAL ECONOMY TYPOLOGIES}

In order to gain a better applied understanding of what the informal economy is all about, this part highlights to less statistical side of the informal economy. Obviously, there are many definitions, since informal economy can include the street vendor in Nepal as much as the software consultant moonlighting in Silicon Valley, in this context, both developed and developing countries are host to an informal economy with working differences. Typically, such a perspective will come up with the following characteristics:

- Labor-intensive

- Use of simple techniques and technologies

- $\quad$ No or little qualification

- $\quad$ Small and micro businesses such as family run business

- $\quad$ Processing of mostly local raw materials

- $\quad$ Lack of social security

- $\quad$ Comparatively low payment and poor working conditions

After considering above characteristics, the informal sector or employment in it with a set of survival activities performed by destitute people on the margins of society. Most of the individuals engaged in informal economic activities are poor, particularly in the third world, informal economic processes cut across the whole social structure. Thus informal economy is not a euphemism for poverty. Conversely, many studies point out the economic dynamism of unregulated income generating activities and the relatively high level of income that can even lie above the income level of workers in the formal sector. Indeed, a survey in 1992 in Benin, Africa, showed that the street vendor's income was 1.1 to 4.5 times higher than the legal minimum wage (Van Ginneken, 1997). Nevertheless a much higher percentage of people working in the informal relative to the formal economy are poor, and more than a larger share of women relative to men working in the informal economy are poor (ILO, 2002).

Involvement in the informal economy is generally less in developing countries, it is a matter of choice than a sheer lack of options. In other words, most people do not choose to work in the informal economy but are forced to do so for obvious reasons such as lack of jobs in the formal economy, lack of qualifications and skills necessary to work in the formal economy coupled with easy entry into the informal economy. However, it has also been suggested by some authors that quite a few working people may actively choose informality to avoid paying taxes and complying with regulations, and also to opt out of social insurance schemes and other public services that they consider low quality (Huitfeldt, Jütting, and Jütting, 2009) or of which they might not understand the benefits at all. Usually, employment in informal economy lacks the benefits which might be found in the formal sector, such as social security provisions, labour rights, agreed working hours, long term employment (contract) etc. Hence, while a job in the informal economy may be viewed as a steppingstone to one in the formal economy, it can also be a desirable end in itself, and even shifts from the formal to the informal economy cannot be ruled out.

In most of the developing countries, many economic units try to escape the administrative, legal or statistical framework. It is tempting to label such units as the constituents of an informal economy. The major weakness of this definition 
is country-specific, depend on the prevailing administrative, legal or statistical framework. This sector expands or contracts with a change in the underlying yardstick over time. Somewhat along the same vein, the informal sector is sometimes considered to be outside the scope of planned development efforts and thus ignore productivity, social security and, of course, statistics. As a result, countries have the flexibility to adopt their definition which is appropriate according to their needs and the system of data collection.

\section{STATUS OF INFORMAL SECTOR IN SOME SELECTED COUNTRIES}

The status of informal sector and informal employment in some selected countries give important trend on informal economy in the world. This is helpful to determine the specific policy for future courses of our own country. The size of informal economy outside the agriculture sector of Nepal with her neighboring countries seems quite larger (Table 3). The larger size of informal economy shows instability and less development status of the economy.

Table 3: Employment in the Informal Economy in Non-agricultural Activities in some Selected Countries

\begin{tabular}{|c|c|c|c|c|c|c|}
\hline \multirow[t]{2}{*}{$\begin{array}{c}\text { Country } \\
\text { (year) }\end{array}$} & \multicolumn{2}{|c|}{$\begin{array}{l}\text { Persons in } \\
\text { informal } \\
\text { employment }\end{array}$} & \multicolumn{2}{|c|}{$\begin{array}{c}\text { Persons employed } \\
\text { in the informal } \\
\text { sector }\end{array}$} & \multicolumn{2}{|c|}{$\begin{array}{c}\text { Persons in } \\
\text { informal } \\
\text { employment } \\
\text { outside the } \\
\text { informal sector }\end{array}$} \\
\hline & $\begin{array}{l}\text { In } \\
, 000\end{array}$ & $\begin{array}{c}\text { \% of } \\
\text { non-agr. } \\
\text { employ- } \\
\text { ment } \\
\end{array}$ & $\begin{array}{l}\text { In } \\
900\end{array}$ & $\begin{array}{c}\text { \% of } \\
\text { non- agr. } \\
\text { employ- } \\
\text { ment }\end{array}$ & $\begin{array}{l}\text { In } \\
, 000\end{array}$ & $\begin{array}{c}\text { \% of } \\
\text { non-agr. } \\
\text { employ- } \\
\text { ment } \\
\end{array}$ \\
\hline Argentina (2009) & 5138 & 49.7 & 3317 & 32.1 & 1850 & 17.9 \\
\hline Brazil (2009) & 32493 & 42.2 & 18688 & 24.3 & 13862 & 18.0 \\
\hline China (2010) & 36030 & 32.6 & 24220 & 21.9 & 13850 & 12.5 \\
\hline India $(2009 / 10)$ & 185876 & 83.6 & 150113 & 67.5 & 37409 & 16.8 \\
\hline Nepal (2008) & 2655 & 86.4 & 2142 & 69.7 & 932 & 30.3 \\
\hline Pakistan $(2009 / 10)$ & 21913 & 78.4 & 20416 & 73.0 & 2319 & 8.3 \\
\hline South Africa (2010) & 4089 & 32.7 & 2225 & 17.8 & 1864 & 14.9 \\
\hline Sri Lanka (2009) & 3184 & 62.1 & 2588 & 50.5 & 597 & 11.6 \\
\hline Viet Nam (2009) & 17172 & 68.2 & 10948 & 43.5 & 6303 & 25 \\
\hline
\end{tabular}

Source: ILO, Department of Statistics- 2012;

http://laborsta.ilo.org/informal_economy_E.html

Gender-wise involvement in the informal sector activities is another measuring tools of the development. In most of the developing countries, size of female involvement in informal sector was found to be larger compare to developed countries. Following Table 4 depicts the persons involvement in informal employment, informal sector and outside the informal sector on gender basis in some selected countries. In most of the developing countries the proportion of female in informal sector activities were found to be larger. 
Table 4: Gender-wise Employment in the Informal Economy in Non-agricultural Activities in some Selected Countries

\begin{tabular}{|c|c|c|c|c|c|c|c|}
\hline \multirow{2}{*}{\multicolumn{2}{|c|}{$\begin{array}{c}\text { Country } \\
\text { (year) }\end{array}$}} & \multicolumn{2}{|c|}{$\begin{array}{c}\text { Persons in } \\
\text { informal } \\
\text { employment }\end{array}$} & \multicolumn{2}{|c|}{$\begin{array}{c}\text { Persons } \\
\text { employed in the } \\
\text { informal sector }\end{array}$} & \multicolumn{2}{|c|}{$\begin{array}{c}\text { Persons in } \\
\text { informal } \\
\text { employment } \\
\text { outside the } \\
\text { informal sector }\end{array}$} \\
\hline & & $\begin{array}{l}\text { In } \\
900\end{array}$ & $\begin{array}{c}\text { \% of } \\
\text { non- } \\
\text { agr. } \\
\text { employ- } \\
\text { ment }\end{array}$ & $\begin{array}{l}\text { In } \\
\text { O000 }\end{array}$ & $\begin{array}{c}\text { \% of } \\
\text { non- } \\
\text { agr. } \\
\text { employ- } \\
\text { ment }\end{array}$ & $\operatorname{In}_{\mathfrak{0 0 0}}$ & $\begin{array}{c}\text { \% of } \\
\text { non- } \\
\text { agr. } \\
\text { employ } \\
\text {-ment }\end{array}$ \\
\hline \multirow[t]{2}{*}{ Argentina (2009) } & $\mathrm{F}$ & 2189 & 49.6 & 1131 & 25.7 & 1071 & 24.3 \\
\hline & $\mathrm{M}$ & 2949 & 49.8 & 2186 & 36.9 & 779 & 13.2 \\
\hline \multirow[t]{2}{*}{ Brazil (2009) } & $\mathrm{F}$ & 15909 & 45.9 & 6982 & 20.1 & 8944 & 25.8 \\
\hline & $\mathrm{M}$ & 16585 & 39.2 & 11706 & 27.7 & 4918 & 11.6 \\
\hline \multirow[t]{2}{*}{ China (2010) } & $\mathrm{F}$ & 17230 & 35.7 & 11150 & 23.1 & 7100 & 14.7 \\
\hline & $\mathrm{M}$ & 18794 & 30.1 & 13062 & 20.9 & 6761 & 10.8 \\
\hline \multirow[t]{2}{*}{ India $(2009 / 10)$} & $\mathrm{F}$ & 34921 & 84.7 & 24475 & 59.4 & 10793 & 26.2 \\
\hline & $\mathrm{M}$ & 150955 & 83.3 & 125639 & 69.4 & 26615 & 14.7 \\
\hline \multirow[t]{2}{*}{ Pakistan (2009/10) } & $\mathrm{F}$ & 2079 & 75.7 & 1979 & 72.1 & 219 & 8.0 \\
\hline & $\mathrm{M}$ & 19834 & 78.7 & 18437 & 73.1 & 2100 & 8.3 \\
\hline \multirow{2}{*}{$\begin{array}{l}\text { South Africa } \\
(2010)\end{array}$} & $\mathrm{F}$ & 2018 & 36.8 & 922 & 16.8 & 1096 & 20.0 \\
\hline & $\mathrm{M}$ & 2071 & 29.5 & 1303 & 18.6 & 768 & 10.9 \\
\hline \multirow[t]{2}{*}{ Nepal (2008) } & $\mathrm{F}$ & 904 & 91.8 & 763 & 77.5 & 221 & 22.5 \\
\hline & $\mathrm{M}$ & 1751 & 83.8 & 1379 & 66.0 & 711 & 34.0 \\
\hline \multirow[t]{2}{*}{ Sri Lanka (2009) } & $\mathrm{F}$ & 933 & 55.7 & 700 & 41.8 & 232 & 13.9 \\
\hline & $\mathrm{M}$ & 2252 & 65.2 & 1888 & 54.7 & 364 & 10.6 \\
\hline \multirow[t]{2}{*}{ Viet Nam (2009) } & $\mathrm{F}$ & 7800 & 66.8 & 5106 & 43.7 & 2738 & 23.4 \\
\hline & $\mathrm{M}$ & 9372 & 69.4 & 5842 & 43.3 & 3565 & 26.4 \\
\hline
\end{tabular}

Source: ILO, Department of Statistics- 2012;

$$
\text { http://laborsta.ilo.org/informal_economy_E.html }
$$

The economic status of the country can be identified on the basis of involvement of persons in informal employment, informal sector, labour force participation rate, unemployment rate, GDP per capita and poverty level of the country. The information of above macro-economic parameters are generally followed by all nation. The economic status of Nepal was found relatively to be very poor among these selected countries on the basis of macro-economic parameters (Table 5). 
Table 5: Some Selected Countries and Indicators

\begin{tabular}{|c|c|c|c|c|c|c|}
\hline \multirow[t]{2}{*}{ Country } & $\begin{array}{l}\text { Persons } \\
\text { in } \\
\text { informal } \\
\text { employ- } \\
\text { ment } \\
\end{array}$ & $\begin{array}{c}\text { Persons } \\
\text { employed } \\
\text { in } \\
\text { informal } \\
\text { sector } \\
\end{array}$ & $\begin{array}{l}\text { Labour } \\
\text { force } \\
\text { parti- } \\
\text { cipation } \\
\text { rate }\end{array}$ & $\begin{array}{l}\text { Unemploy- } \\
\text { ment rate }\end{array}$ & $\begin{array}{l}\text { GDP per } \\
\text { capita }\end{array}$ & Poverty line \\
\hline & $\begin{array}{c}\text { \% of } \\
\text { non-agr. } \\
\text { employ- } \\
\text { ment }\end{array}$ & $\begin{array}{c}\text { \% of } \\
\text { non-agr. } \\
\text { employ- } \\
\text { ment }\end{array}$ & $\begin{array}{c}\% \text { of } \\
\text { working } \\
\text { age } \\
\text { population }\end{array}$ & $\begin{array}{c}\text { \%o of } \\
\text { econo- } \\
\text { mically } \\
\text { active } \\
\text { population }\end{array}$ & $\begin{array}{c}\text { US \$ } \\
\text { (year 2010) }\end{array}$ & $\begin{array}{c}\text { \% of pop. } \\
\text { Living } \\
\text { below } \\
\text { national } \\
\text { poverty line }\end{array}$ \\
\hline Argentina & 49.7 & 32.1 & 46 & 7.7 & 9138 & $\mathrm{Na}$ \\
\hline Brazil & 42.2 & 24.3 & 62 & 7.1 & 10816 & 21.4 \\
\hline China & 32.6 & 21.9 & 70.1 & 4.1 & 4382 & 2.8 \\
\hline Egypt & 51.2 & $\mathrm{Na}$ & 33 & 9 & 2789 & 22.0 \\
\hline India & 83.6 & 67.5 & 39.1 & 4.3 & 1265 & 27.5 \\
\hline Pakistan & 78.4 & 73 & 32.2 & 5.2 & 1050 & 22.3 \\
\hline Nepal & 68.4 & 69.7 & 83.4 & 2.1 & 645 & 25.16 \\
\hline Sri Lanka & 62.1 & 50.5 & 49.2 & 5.7 & 2435 & 15.2 \\
\hline Thailand & 42.3 & $\mathrm{Na}$ & 71.9 & 1 & 4992 & 8.1 \\
\hline Viet Nam & 68.2 & 43.5 & 71.4 & 2.1 & 1174 & 14.5 \\
\hline
\end{tabular}

Source: ILO, Department of Statistics-2012;

http://laborsta.ilo.org/informal_economy_E.html

Nepalese case is tried to be identified with the help of a sample district, Chitwan to estimate the employment and income generation in informal sector. The information of informal sector in the district was collected through field survey in 2005. Nepal labour force survey-2008 about informal sector and informal employment has been considered after field survey. The later national survey was limited on the distribution of the persons only on the various informal sector activities not on their economic status of various informal sector activities. That means, this field survey is still valid for economic analysis. This paper also attempts to estimate the employment and income generation in both male and female earning status.

Poverty in Nepal, like many other developing countries, is mainly concerned with absolute poverty i.e. people's survival without basic means of living and nourishment. Nepal has a large section of population under poverty. In 1995-96, 41.76 percent of the country's population was below poverty line which has become 30.85 percent in 2003-04 poverty line has come down to 25.39 percent in the fiscal year 2008/09. The World Bank has redefined US\$ 1.25 a day as the poverty line in 2005. However, the poverty situation of Nepal has still followed the earlier parameter of poverty. The poverty has been more in the rural area than in the urban area. Employment scenario in the economy was very discouraging which became worse due to internal conflict. According to the Economic Survey 2009-10, in Nepal 2.1 percent of the population (10 years and above) was unemployed. However, according to the Nepal Living Standard Survey 2003-04, 2.9 percent of the population aged 15 years and above was unemployed. The incidence of unemployment was more among the males than females. The youth unemployment rate was quite high at 15.0 percent causing a situation of economic distress in the economy. According to Nepal Living Standard Survey (NLSS) of 2003/04, the incidence of poverty was 30.9 percent. It is come down from the previous estimate of $1995 / 96$ (41.8 percent), even so still it is 


\section{EVALUATION OF INVESTMENT AND RETURN ...}

high. According to the Tenth Plan, the number of economically active population was estimated to reach to 11.6 million toward the end of the plan period, out of which only 4.1 percent were estimated to remain unemployed (Economic Survey 2008/09). The Nepal Labor Force Survey (NLFS) -2008 has estimated that the current labor force participation rate (the proportion of population aged 15 years and above who were currently economically active) decreased marginally from 85.8 percent in 1998/99 to 83.4 percent in 2008. The time-related underemployment rate for the population of 15 years and above is 6.7 percent in 2008 as compared to 4.1 percent in 1998/99, but decline (2.1 percent) in 2009/10.

Government of Nepal is continuously trying to reduce poverty and unemployment, but the situation seems to be still not fully manageable due to various reasons like structural constraints, poor governance, political conflict, etc. The Nepalese economy is still under the grip of low economic growth rate. Gross domestic savings rate was 7.4 percent in 2009/10 and the gross investment was 20.2 percent necessitating huge amount of borrowings or transfer from abroad by the Nepalese workers abroad. This is also reflected in huge gap between exports and imports leading to wide trade deficit (46.5 percent in 2009/10) and even goes up further. However, a large number of Nepalese workers working abroad have been a great source of relief to the economy as their remittances have been around 10.5 percent change of the GDP. Thus, the economy does not seem to be moving properly and sufficiently to imbibe a sense of confidence even in the modern economic activities as we have already seen that the non-farm sectors' performances have not been encouraging despite the country receiving huge amount in terms of remittances.

\section{OBJECTIVES OF THE STUDY}

The general objective of this study is to analyze the pattern of employment and income generation in informal sector. The specific objectives are as follows:

- $\quad$ to determine employment pattern in informal sector,

- $\quad$ to highlight investment status of informal sector,

- $\quad$ to estimate income earning activities of informal sector

\section{METHODOLOGY}

Survey data on the informal sector can be obtained with acceptable quality provided the survey design and operations are adapted to the particular characteristics of the informal sector. This may require modifications of traditional survey methods or even the development of new methods. Informal sector employment and/or unregistered employment have been measured through household surveys by a large number of countries. In Nepal, unregistered employment used to take information from informal sector through 'Report on the Nepal Labor Force Survey-1998/99'. Present study assumes the informal sector activities to be unregistered. Mixed household and enterprise surveys found to be the most suitable survey approach for the collection of comprehensive data of informal sector as a whole along with various segments.

The sources of information were based on rural and urban areas of Chitwan district. This study has mainly followed survey method to collect information from rural areas. Stratified activities of informal sector are taken into consideration according to density and size of different types of occupations. Some types of informal sector 
activities which tend to be concentrated heavily in specific areas, with a view to ensuring an adequate representation of all such activities in the sample and reducing clustering effects which may be seen in urban areas. For the coverage of homeless respondents of the informal sector, attempts were made to obtain the information at the working spot both in urban as well as rural locations. In fact, many people do not have their permanent houses and venue of business activities. Their works remain mobile in nature like roaming on bicycle and to go to different market places as they sell their products in weekly based markets i.e. haats or while taking the items on their heads or some carts or animals, etc. Data were collected from their working place of work accordingly. Many informal sector activities are subject to seasonal and other variations over time. The information of informal sector activities were taken within three months' period (April to June 2005) and the questionnaires have included most of the activities which are done within one year and at the time of interview.

To explain about the informal sector earning function under sex and location, multiple regression analysis has been used according to the nature of variables. How the informal sector earning has been affected by changing labour forces, investment, and education has also examined using multiple regression analysis in log linear form i.e., Cobb-Douglas types of production function.

Functional relation, $Y_{i}=\mathrm{f}$ (ISL, INV, LITL) in Cobb-Douglas production form: $Y_{i}=A \times I S L^{\beta_{1 i}} \times I N V^{\beta_{2 i}} \times L I T L^{\beta_{3 i}} \times u_{i}$ Where $\beta_{1}+\beta_{2}+\beta_{3}=1$ Using natural $\log , \log _{e} Y_{i}=\beta_{0 i}+\beta_{1 i} \log _{e} I S L+\beta_{2 i} \log _{e} I N V+\beta_{3 i} \log _{e} L I T L+v_{i}$, assuming $\log$ linear form of the function.

Where

$Y_{i}=$ Per - day household earning from informal sector,

ISL $=$ No. of supply of labour in informal sector activities,

INV = per - day household investment in informal sector activities,

LITL $=$ Literacy level (No. of years of schooling) of the respondent,

$\log _{e}=$ natural $\log$ based on ' $\mathrm{e}$ '

$\beta_{0}=\log _{e} A$ is constant,

$\beta_{1}=$ elasticity of no. of supply of labor in informal sector (ISL),

$\beta_{2}=$ elasticity of investment (NRs) per - day (INV), and

$\beta_{3}=$ elasticity of literacy level (no. of years of schooling) of the respondent (LITL) $\log _{e} u_{i}=v_{i}$,

Under the three explanatory variables (ISL, INV, LITL) the various models of earning functions have been estimated with the version of SPSS-20.

\section{PATTERN OF EMPLOYMENT}

The study did not make any comparison with formal sector due to the lack of comparable data. It is believed that the informal sector is managed by one's own labor 


\section{EVALUATION OF INVESTMENT AND RETURN ...}

as well family labor and sometimes hired labor too. (Table-6), almost three-quarters (73.4 percent) of the units were run by the respondents by themselves or with the support of the family members. It is further interesting to observe that almost 18 percent of the units were run where the respondents were not working and the work was being done by the family members or wage earners. In some cases even unpaid workers were employed and they were simply hired casually on subsistence basis without paying any regular wage in cash. There is further degree of informality within the informal sector. Thus, if people are engaged from outside the family, it could be wage earners as well as unpaid workers. The latter hints at the prevalence of large scale poverty in the area that may force some people to work just for subsistence and they do not insist on wage payments in cash due to lack of bargaining power.

The pattern of engagement or employment differs according to male and female run units. Male respondents mostly depend (43.2 percent) on self-employment followed by engagement of family members (26.9 percent) whereas women respondents mainly and with greater emphasis depend upon family support (57.3 percent) followed by self-employment (24.7 percent). Hence, a conclusion can be drawn that the women are more articulate in mobilizing household support unlike their male counterparts who basically depend upon themselves or wage earners and unpaid workers. Women generally do not prefer to employ wage earners when they themselves are involved. However, when they are not directly involved may hire wage earners along with family members. Thus, women entrepreneurs mainly depend upon household support and themselves whereas men depend upon themselves, household and wage earners as well as unpaid workers.

The number of the workers in any enterprise makes impact on the overall earnings from any informal sector enterprise. Besides, there are other likely determinants. We now make efforts to estimate the income function in the informal sector in Chitwan district based upon data collected from a large number of respondents.

\section{INVESTMENT STATUS}

It would be helpful to understand different parameters which seemingly play crucial role in determination of income and employment in the informal sector before moving to estimate employment and earnings from the informal sector activities. Table 4 offers information on some major dimensions. Average initial investment was higher in the urban area than in the rural location. There appears to be lower initial investments in the units run by the females. Probably this is the reason that the reinvestment period is somewhat lower in case of the female respondents. Thus, women entrepreneurs were found to use the investments with greater efficiency as the reinvestment amount was also found to be lower by the women than men. Women entrepreneurs seem to be more helpful in employment generation in all the locations. Besides, they also get greater support from the household members in running their business. However, the training imparted to them, as discussed above, has been far lower in all the locations. These points suggest that despite being more efficient, there is some in-built system of bias against the women entrepreneurs. It is because of women entrepreneurs, who are more articulate in mobilizing resources through the microfinance activities as the governmental financial support was found to be too little as in the total sample only 13 respondents (that is, around 3 percent only) could benefit and was mainly in the rural area. 
In informal sector activities due to the diversify nature, the size of investment and re-investment was found to be vast differences to each other's. However, the average re-investment period was around 3 days (2.61 days). The size of average initial investment in rural areas compared to urban areas for females was found to be larger but for males, the size of initial investment in urban locations was greater than rural one. Average per day investment for females was found to be greater in size and relatively larger in urban areas.

Table 6: Investment Status in Informal Sector by Sex and Location

\begin{tabular}{|l|l|r|r|r|}
\hline Location & Sex & $\begin{array}{c}\text { Re-investment } \\
\text { periods } \\
\text { (number of days) }\end{array}$ & $\begin{array}{c}\text { Initial investment } \\
\text { (NRs) }\end{array}$ & $\begin{array}{c}\text { Per day } \\
\text { investment } \\
\text { (NRs) }\end{array}$ \\
\hline \multirow{2}{*}{$U_{1}$} & Male & $2.29(133)$ & $3841.20(122)$ & $653.87(122)$ \\
\cline { 2 - 5 } & Female & $2.33(57)$ & $2683.47(62)$ & $711.31(62)$ \\
\hline \multirow{2}{*}{$U_{2}$} & Male & $2.86(56)$ & $3721.82(61)$ & $332.35(61)$ \\
\cline { 2 - 5 } & Female & $1.90(21)$ & $2738.10(21)$ & $587.38(21)$ \\
\hline \multirow{2}{*}{ Rural } & Male & $3.30(108)$ & $2905.95(118)$ & $384.63(118)$ \\
\cline { 2 - 5 } & Female & $2.03(34)$ & $3667.79(34)$ & $481.74(34)$ \\
\hline All & & $\mathbf{2 . 6 1 ( 3 8 9 )}$ & $\mathbf{3 3 1 5 . 5 5 ( 4 1 8 )}$ & $\mathbf{5 2 2 . 1 2 ( 4 1 8 )}$ \\
\hline
\end{tabular}

Source: Field survey 2005, Figures within parentheses are number of the respondents.

Table 7 shows the internal relation between investment rate with their returns. However, the both absolute size of investment and earning were found small. The earning capacity and investment rate of female was found to be higher in each location compare to male due to diversify nature of activities in informal sector. By taking an example of fruit selling, or clothes selling work which are found generally done by female while the activities of cart pulling work or rickshaw pulling work are seemed to be mostly done by male where the rate of earning and investment size were found differ itself by their nature of work. The size of investment was found to be positively related to the development status and it was more vary in comparison to their rate of returns. However, the statistical figures show that the variation between genders as well as between locations was not found to be much difference.

Table 7: Invest and Earning Status in Informal Sector

\begin{tabular}{|c|l|l|r|r|r|r|}
\hline Location & Sex & Status (in Rs.) & Mean & \multicolumn{1}{l|}{ Variance } & \multicolumn{1}{c|}{ Skewness } & Kurtosis \\
\hline \multirow{3}{*}{$\mathrm{U}_{1}$} & Male & Daily investment & 653.87 & 1624284.46 & 4.56 & 26.65 \\
\cline { 2 - 7 } & $(122)$ & Daily earning & 290.41 & 33856.21 & 2.37 & 9.04 \\
\cline { 2 - 7 } & Female & Daily investment & 711.31 & 720403.32 & 3.17 & 13.01 \\
\cline { 2 - 7 } & $(62)$ & Daily earning & 304.69 & 36323.18 & 2.73 & 12.87 \\
\hline \multirow{4}{*}{$U_{2}$} & Male & Daily investment & 332.35 & 250175.34 & 1.97 & 3.17 \\
\cline { 2 - 7 } & $(61)$ & Daily earning & 201.07 & 14521.67 & 1.69 & 3.85 \\
\cline { 2 - 7 } & Female & Daily investment & 587.38 & 398509.46 & 2.30 & 11.13 \\
\cline { 3 - 7 } & $(21)$ & Daily earning & 221.67 & 23856.67 & 1.39 & 2.15 \\
\hline \multirow{5}{*}{ Rural } & Male & Daily investment & 384.63 & 355021.71 & 2.70 & 9.23 \\
\cline { 2 - 7 } & $(118)$ & Daily earning & 198.60 & 24284.21 & 2.95 & 14.18 \\
\cline { 2 - 7 } & Female & Daily investment & 481.74 & 276059.65 & 3.69 & 16.42 \\
\cline { 2 - 7 } & $(34)$ & Daily earning & 223.63 & 24158.33 & 2.29 & 7.28 \\
\hline
\end{tabular}

Source: Field survey 2005, Figures within parentheses are number of the respondents 


\section{ESTIMATION OF INCOME EARNING FUNCTIONS UNDER SEX AND LOCATION}

The determinants of informal sector earning in the study preliminary had been cited as number of labour employed, investment level, literacy level of the workers, household property, training level, etc. However, in most of the cases, the empirical study shows that the first three factors have been included as the main explanatory variables for the determination of informal sector earning and the remaining other factors have been found insignificant effect in the sharing of earning in all cases.

Table 8: Estimation of Income Earning Functions between Male and Female

\begin{tabular}{|c|c|c|c|c|c|c|c|}
\hline Sex & Dependent variable & \multicolumn{4}{|c|}{ Independent variables } & $R^{2}$ & F-test \\
\hline \multirow[t]{5}{*}{ Male } & Income & Const & ISL & INV & LITL & \multirow{5}{*}{0.884} & \multirow{4}{*}{564.29} \\
\hline & \multirow[t]{2}{*}{ Coefficients } & $\beta_{0}$ & $\beta_{1}$ & $\beta_{2}$ & $\beta_{3}$ & & \\
\hline & & 9.075 & 0.094 & 0.037 & 0.867 & & \\
\hline & t-value & 141.0 & 3.381 & 1.438 & 30.43 & & \\
\hline & p-value & 0.000 & 0.001 & 0.152 & 0.000 & & 0.000 \\
\hline \multirow[t]{5}{*}{ Female } & Income & const & ISL & INV & $\overline{\text { LITL }}$ & \multirow[t]{5}{*}{0.874} & \multirow[t]{4}{*}{200.599} \\
\hline & \multirow[t]{2}{*}{ Coefficients } & $\beta_{0}$ & $\beta_{1}$ & $\beta_{2}$ & $\beta_{3}$ & & \\
\hline & & 8.674 & 0.083 & 0.150 & 0.818 & & \\
\hline & t-value & 68.936 & 1.905 & 3.557 & 17.496 & & \\
\hline & p-value & 0.000 & 0.060 & 0.001 & 0.000 & & 0.000 \\
\hline
\end{tabular}

Source: Field Survey 2005.

Estimation of income earning functions between sex in Table 8 shows that only labour input and literacy level of the male respondents have been found significance (at one percent level) for the determination of informal sector earning while for female respondents amount of investment and literacy level are found to be significant (one percent level) factors of income. Most of the male respondents engaged in Rickshaw pulling work, cycle repair and pumping work, shoe repair and polishing work, cycle repair and pumping work, hair dresser, etc. These are informal sector activities where a fixed amount of investment has been used and their earning is based on physical activities and the bargaining capacity. That means investment is not significant factor of earnings. Males were based mainly on physical labour compared to a large amount of investment. On the other hand female based activities are Fruit seller, non consumption foods, foot path based toilet, small tea shop, etc. where relatively larger amount of investment are required with a limited number of labor. In female based activities, the investment and bargaining power (level of literacy) are the significant factors for their per capita earnings.

\section{CONCLUSION}

The people engaged in the informal sector are spread in the urban as well as rural areas. The activities are highly diversified and heterogeneous in nature. The informal sector entrepreneurs may not remain confined to oneself or family labor. They also employ wage earners and others if need. The pattern of 
investment in informal sector was also found differ due to heterogeneous nature of informal activities. It is more complicated to generalize in each case. Thus, this sector also provides direct employment besides likely possibilities of generating indirect employment. Women are found to be more articulate in mobilizing family participation in their businesses. Income generation in the informal sector seems to have some common pattern both in rural and urban locations. Literacy level of the respondents and households are found to be the most important determinant. Daily level of investments in the business is not so high; still this has some effect in some contexts. Same is the true for household labor as well as wage earners employed in the informal sector units.

However, the informal sector has been helpful in income generation for the stakeholders and it has been helpful in employment generation and poverty reduction in Nepal. The earnings made from the informal sector has been instrumental in taking out the households from the poverty and almost half of the households have been moved to middle income level and even high income category signifying role of the informal sector in reducing poverty. It is concluded that, the state support has been quite low. The state may help the participants of the informal sector in direct as well as indirect manners. Through indirect method may help in raising the literacy and help in skill generation etc. Women should be given greater prominence as they are found to be more efficient not only themselves in many ways but also in mobilizing household participation and using the scarce resources more efficiently. Thus, there should be a coherent policy strategy to tap the potentialities of the women by some meaningful interventions keeping the local conditions into mind because uniform policy may not be applicable throughout the country. The size of informal economy is significant but sufficient policies have not been developed yet. Most of the marginal poor except agriculture sector are found, however the specific policy and activities have not formed. If the specific policy is launched to the informal sector activities to reduce its size then it will be more important to forecast and control the Nepalese economy according to their priority objectives.

Source note from Box 1: Nepal Labour Force Survey, Central Bureau of Statistics, National Planning Commission Secretariat, Government of Nepal, 2008; Note: Cells shaded in black refer to jobs, which, by definition, do not exist in the type of production unit in question. Cells shaded in light grey refer to formal jobs. Un-shaded cells represent the various types of informal jobs as outlined Employment in the informal sector encompasses the cells in the second row. Informal employment encompasses all white cells. The white cells in the first and third row are called informal employment outside the informal sector.

\section{WORKS CITED}

Breman, I.C. (1980). The Informal Sector in Research: Theory and Practice. Comparative Asian Studies Programme, (CASP). Erasmus University, Rotterdam.

Central Bureau of Statistics, (2006). Nepal Living Standard Survey 2003/04. National Planning Commission Secretariat Government of Nepal, Kathmandu. 
--- (2007). Population Profile of Nepal. National Planning Commission Secretariat, Government of Nepal, Kathmandu.

--- (2009). Report on the Nepal Labour Force Survey 2008. National Planning Commission Secretariat, Government of Nepal, Kathmandu.

Chiang, Alpha C. (1974). Fundamental Methods of Mathematical Economics. 2nd ed. International Student Edition, McGrawal-Hill Kogakusha Ltd. Tokyo, Japan.

Dhakal, R.C. (2010). "Impact of Informal Sector on Poverty and Employment in Nepal: A Micro Level Study of Chitwan District" The Economic Journal of Nepal. Vol. 33, No. 2, April-June 2010 (issue no. 130): 106-125, CEDECON, TU, Kirtipur, Kathmandu.

--- (2012). "Informal Sector in Nepal: A Case Study of Chitwan District" Pragya Sarathi. Year 11, Vol. 10, April 2012; 105-118, TUTA Campus Unit, Dhawalagiri Multiple Campus, Baglung.

Gërxhani, Klarita. (2004). The Informal Sector in Developed and Less Developed Countries: A Literature Surve. Public Choice, 120 (3/4): 267-300.

Government of Nepal (1999). Report on the Nepal Labor Force Survey-1998/99. CBS, National Planning Commission Secretariat, Kathmandu.

--- (2007). Three Year Interim Plan (2007/08-2009-10). National Planning Commission Secretariat, Kathmandu.

Hart, K. (1970). "Small Scale Entrepreneurs in Ghana and Development Planning”. Journal of Development Studies. 6 (1):104-120.

--- (1973). "Informal Income Opportunities and Urban Employment in Ghana. "Journal of Modern African Studies. 11 (1): 61-89.

Hasan, Arif. (2002). "The changing nature of the informal sector in Karachi as a result of global restructuring and liberalization." Environment and Urbanization, 14 (1): 69-78.

Hofmann, Michael (1986). "The Informal Sector in an Intermediate City: A Case in Egypt". Economic Development and Cultural Change, 34 (2): 263277.

Huitfeldt, H., Jütting, S., and Jütting, J. (2009). Informality and Informal Employment. OECD, Paris.

Hussmanns, R. (2004). Statistical definition of informal employment: Guidelines endorsed by the Seventeenth International Conference of Labour Statisticians (2003). International Labour Organization, Geneva.

--- (2005). Measuring the informal economy: From employment in the informal sector to informal employment. International Labour Organization, Geneva. 
ILO (2003). Seventeenth International Conference of Labour Statisticians (2003). International Labour organization, Geneva.

--- (2012). Department of Statistics, ILO, Geneva- 2012; retrieved from the web site: http://laborsta.ilo.org/informal_economy_E.html.

--- (2002). Decent work and the informal economy. International Labour organization, Geneva.

--- (2004). Social Protection for People in the Informal Economy of Nepal. Kathmandu.

--- (2010). Extending the Scope of Application of Labour Laws to the Informal Economy. International Labour Organization, Geneva.

Jonakin, Jon. (2006). "Cycling between Vice and Virtue: Assessing the Informal Sector's Awkward Role under Neoliberal Reform". Review of International Political Economy. 13 (2): 290-312.

Kantor, Paula (2002). A Sectoral Approach to the Study of Gender Constraints on Economic Opportunities in the Informal Sector in India. Gender and Society, 16 (3): 285-302, Labour Organization.

Leach, Fiona (1996). "Women in the Informal Sector - The Contribution of Education and Training". Development in Practice, 6 (1): 25-36.

Marcouiller, Douglas, Veronica Ruiz de Castilla and Christopher Woodruff (1997). Formal Measures of the Informal-Sector Wage Gap in Mexico, El Salvador, and Peru. Economic Development and Cultural Change. 45(2): 367-392.

Ministry of Finance (2008). Economic Survey - Fiscal Year 2007-08. Government of Nepal, Kathmandu.

--- (2009). Economic Survey - Fiscal Year 2008/09. Government of Nepal, Kathmandu.

--- (2010). Economic Survey - Fiscal Year 2009/10. Government of Nepal, Kathmandu.

--- (2011). Economic Survey - Fiscal Year 2010/11. Government of Nepal, Kathmandu.

Papola, T.S. (1980). Informal sector: Concept and policy. Economic and Political Weekly. 15 (18): 817-824.

Romatet, Emmannuel (1983). Calcutta's Informal Sector: Theory and Reality. Economic and Political Weekly. 18 (50): 2115-2128.

Schneider, Friedrich (2002). Size and Measurement of the Informal Economy in 110 Countries Around the World. Retrieved from; http:/www.economics.uni-linz.ac.at.

Skinner, Caroline and Imraan Valodia (2003). Local Government Support for Women in the Informal Economy in Durban, South Africa. International 
Journal of Politics. Culture and Society, 16 (3), Toward Gender Equity: Policies and Strategies: 431-444. Durban, South Africa.

UNDP.(2009). Human Development Report 2009 - Overcoming Barriers Human Mobility and Development. United Nations Development Program, New York.

United Nations Economic and Social Council (2006). Poverty and the Informal Sector. Committee on Poverty Reduction, Economic and Social Commission for Asia and Pacific, Bangkok.

Van Ginneken (1997). Social Security for the Informal Sector: Investigating the feasibility of a Pilot Project in Salvador and Tanzania. Issues in Social Protection, Discussion Paper number 5. 